\title{
Animal Substitution as a Reversed Sacrifice: An Intertextual Reading of Genesis 22 and the Animal Stories of Shūsaku Endō
}

\author{
Sigrid Coenradie
}

1

Introduction

In Genesis 22, God provides an animal substitute for a human sacrifice. It is of note that God was also the intended receiver of the sacrifice, as Abraham was required to sacrifice his son to God. Therefore, I will call these animals 'reversed' substitute sacrifices, which emphasizes the idea of sacrifice as a gift. I will start with a reflection on the critique of Levinas on Kierkegaard's interpretation of Genesis 22, and read the result against the various stories on 'reversed' sacrificial substitution in the oeuvre of the Japanese Catholic author Shūsaku Endō (1923-1996), in which a bird or a dog are substituted for dying humans. Next, I will stress two major differences between the biblical story and Endō's stories of animal substitutes:

1. In the story of Abraham and Isaac, it is God who gives the ram to prevent Abraham from sacrificing his youngest son. In contrast to the biblical story, the 'giver' in Endō's narratives of sacrificial substitution is anonymous. This difference is significant in relation to the second difference, the role of the females in the stories.

2. In the story of Abraham and Isaac, the relationship between Abraham and God seems to take priority over the human relationships of Abraham and his wife Sarah, his son Isaac and his servant / friend Eliezer, whereas the relationship of the main character in Endō's stories to the unknown giver of the animal substitute seems to improve the relationship to his family. This difference is, as I will argue, significant for approaching substitution as a gift instead of a sacrifice. I will elaborate on both differences, in order to contribute to reflection on the concept of sacrificial substitution.

Drawing on philosophical theories on giving and receiving, I will analyse and compare the nature of sacrificial substitution in Genesis 22 and in several of Shūsaku Endō's stories. Sacrifice is, next to a religious theme, an event, and in most cases a drama. For understanding the concept, it is necessary to study it in praxis. Fiction can be regarded as solidified experience, and hence have an eye-opening quality. Literature is "an exploration of the abyss: The author's 
and our own". ${ }^{1}$ Thus, literature can stimulate religious awareness and contribute to theological reflection. Applying this to Genesis 22, I will use Endō's narratives on sacrificial substitution to criticize Abraham's morality. Furthermore, this intertextual reading of Endō's 'animal' stories will give rise to a different interpretation of the sacrifice in the biblical story.

\section{$2 \quad$ The Given Animal in Genesis 22}

Animal sacrifice is the practice or an act of ritually slaughtering an animal as an offering to a god or gods. ${ }^{2}$ It is found in many religions as a means of appeasing a god or gods, or to change the course of nature. The identity of someone performing the sacrifice is symbolically transferred to the sacrificial animal, which suffers death on his or her behalf. Animal sacrifices are wellknown in the Hebrew Bible. In Genesis 22, Abraham is willing to sacrifice his son. He is, however, stopped by the provision of a ram that could be sacrificed instead. This chapter will focus on the animals involved. The substitute of the ram caught in a thicket which is sacrificed in place of Isaac is a special case. After God has saved Abraham's first-born son Ishmael and his mother Hagar in the wilderness of Beersheba, He orders Abraham to offer Isaac. Abraham does not protest, and follows the way God has told him to go. He even refrains from informing his family, including his son, about the intent of the journey. On their way to the mountain Moriah, Abraham stops to worship. Then he loads firewood onto Isaac. " "Where is the lamb for a burnt offering?" Isaac asks his father. "God will provide himself the lamb for a burnt offering, my son," Abraham answers. At the supreme moment, when Abraham lifts his knife, he hears an angel's voice which stops him and a substitute ram appears. The animal replaces the son.

In this special case it is the receiver, God, who seems to provide the sacrificial creature. Instead of the son, an animal given by the recipient is sacrificed. Human sacrifice is replaced by animal sacrifice, human death by human life, thus re-establishing the covenant between God and Abraham.

1 A. Blanchet, La Littérature et le Spirituel. La Mêlée Littéraire (Paris: Aubier, 1959), 11.

2 Oxford English Dictionary.

3 On this point the story can has been interpreted as foreshadowing the willingness of God to sacrifice his Son Jesus; just as Isaac carried the wood for his sacrifice up to Mount Moriah, Jesus carried the wood of his sacrifice up to Golgotha. 
Genesis 22 is a complicated story, and its 'inhumane' theme of a father sacrificing his own son calls for interpretations. An important theme seems to be the replacement of child sacrifice with animal sacrifice. It is God who provides for the ram, thereby stressing the difference between the God of Israel and other gods, such as Baal.

In The Binding of Isaac, Religious Murders \& Kabbalah, Lippman Bodoff argues that Abraham never intended to actually sacrifice his son, and that he trusted that God had no intention that he would do so. According to Bodoff, God required that Abraham would persist with what Abraham understood was asked of him, "with faith that the just and righteous God would answer his prayer". ${ }^{4}$ Abraham's prayer during the stop on their way to the mountain was intended to persuade God to intervene, to prevent a terrible injustice from occurring.

Others, such as Dalferth, suggest that Abraham's apparent complicity in the sacrifice was actually his way of testing God. Abraham had previously, in Genesis 18, pleaded with God to save lives in Sodom and Gomorrah. By silently complying with God's instructions to sacrifice Isaac, Abraham was putting pressure on God to act in a moral way to preserve life. ${ }^{5}$ Another indication that Abraham might have thought that he would not actually sacrifice Isaac comes from Genesis 22:5, where Abraham said to his servants, "You stay here with the ass. The boy and I will go up there; we will worship and we will return to you". The use of the word we (as opposed to I) reveals his expectance that both he and Isaac would return. Apparently, he did not believe that Isaac would actually be sacrificed. Likewise, Endō's Numada, by insisting on a "fiftyfifty gamble" operation, is anticipating a good outcome, although in his case it is not clear who the addressee of his challenge is. As I aim to show, comparing Abraham in Genesis 22 to Numada in Deep River brings an alternative interpretation of the former to the fore.

4 Lippman Bodoff, The Binding of Isaac. Religious Murders, and Kabbalah: Seeds of Jewish Extremism and Alienation? (Jerusalem/New York: Devora Publishing Company, 2005), 28.

5 I. U. Dalferth, "Self-sacrifice: From the act of violence to the passion of love," in International Journal for Philosophy of Religion 68 (2010): 77-94 (87). 
Substitution is a dominant theme in the literary work of Shūsaku Endō, one of the outstanding East-Asian authors of the twentieth century. Between 1955 and 1993 he published around 200 titles, including short stories, plays, essays, critical biographies, diaries, and novels. After the publication of Silence (1966), he became famous. Due to his parents' divorce the young Shūsaku moved from Dalian in Manchuria to Japan. He lived in the house of his mother's older sister in Kobe, who was a Catholic. At twelve he was baptized. Endō experienced the "foreign religion" in a country with less than two percent Christians as an "unfitting western suit". ${ }^{7}$ In his literature the struggle with faith is a recurrent theme. Three dissertations highlight the theological themes in Endō's literary work Endō Shūsaku: A Literature of Reconciliation (1999) by Mark B. Williams; Christ in Japanese Culture: Theological Themes in Shusaku Endo's Literary Works (2008) by Emi Mase-Hasegawa; and Transcultural Theodicy in the Fiction of Shūsaku Endō (2009) by Adelino Ascenso. The last study offers a renewed image of Jesus Christ through an analysis of Endō's narratives. ${ }^{8}$

Shūsaku Endō's novel Deep River (1993) is composed around a journey of Japanese tourists to the holy Buddhist places in India. In this novel, the last Shūsaku Endō wrote, each protagonist has his or her own chapter. All protagonists are motivated by a personal desire to undertake the journey, each striving to accomplish a private goal. The theme of animal sacrifice plays a role in two chapters of Deep River. In chapter five, the main characters are Kiguchi and Tsukada. They recollect their past as Japanese soldiers at the end of the Burma campaign. Exhaustion and hunger had driven them to desparation. Kiguchi's friend Tsukada purchased some "lizard meat," which he devoured, whereas Kiguchi was too sick to eat. Not much later the "lizard meat" turned out to be human flesh, the remains of a dead soldier they both knew. In the story of Kiguchi, the 'animal' is believed to have saved the living soldiers' life. ${ }^{9}$ In chapter four, the reader is introduced to Numada, a writer of children's books. He

6 "The Case of Numada" is the title of chapter four in: Shūsaku Endō, Deep River (London: Peter Owen, 1994), 69-83.

7 Shūsaku Endō, "The Anguish of the Alien," The Japanese Christian Quarterly 6/4 (1974): 179-180.

8 Adelino Ascenso, Transcultural Theodicy in the Fiction of Shūsaku Endō (Roma: Editrice Pontificia Università Gregoriana, 2009), 11.

9 The similarity between "The Case of Numada" and "The Case of Kiguchi" is elaborated on by Zhange Ni in "Japan's Orient and Animal Theology in Endō Shūsaku's Deep River," Journal of the American Academy of Religion 81 (2013 No. 3): 669-697. 
uses dogs and birds as main characters in his books, since his first dog Blackie had taught him "that animals can converse with humans" and "he had also learned they can be companions who understand your sorrows". ${ }^{10}$ During his youth, one day Numada took home a stray dog, named Kuro (Blackie). ${ }^{11}$ The filthy dog followed him when he went to school and when he returned in the afternoon. The relationship between Numada's parents was problematic. Often his father came home drunk and his mother was depressed. The young Numada confessed his sorrows to Blackie.

If I live with Dad, that would hurt Mother, and if I live with Mother, that would be a bad thing to do to Dad (...). Blackie had been the one who understood his sorrow in those days, the only living creature who would listen to his complaints: His companion. ${ }^{12}$

When his parents finally got divorced, the boy went with his mother from Manchuria to Japan to live with an aunt in Kobe. The dog had to stay behind. As an adult, Numada was never able to forget the eyes of Blackie, who chased after their carriage as it drove away. The grown-up Numada has a hornbill in his room, called Pierrot, after Rouault's paintings of clowns who symbolize Jesus. ${ }^{13}$ The bird was forced upon the writer by an old man at the local department store, who ran the pet department.

One day he popped up on Numada's doorstep, accompanied by a young man in working clothes, carrying a large furoshiki-wrapped parcel. This fellow's a friend of mine. He has a shop at Shibuy a where he sells little birds and animals. He's just recently got his hands on a hornbill. And here's what I said to him: I know a man like Mr. Numada would want a bird like this. ${ }^{14}$

To his wife's distress, Numada lets the hornbill have free run of his study. When Numada appears to have tuberculosis and is hospitalized, the bird has to be

\footnotetext{
$10 \quad$ Endō, Deep River, 74.

11 The story in Deep River is highly autobiographical. Like Endō, the protagonist Numada is a writer. Like Endō, Numada was raised in Dalian, Manchuria, which at the time had been occupied by the Japanese.

12 Endō, Deep River, 73.

13 Georges Rouault (1871-1958) was a French Catholic expressionist painter and printmaker. From 1917, he specialized in religious themes. The clown-like faces of Jesus and the cries of the women at the feet of the cross in Rouault's work are symbols of the pain of the world. Endō, Deep River, 75 .
} 
returned to the pet shop. During his two years' stay in hospital, Numada had two unsuccessful operations. Now he has pleaded with the physicians to have a third operation, for "it was distasteful to consider staying alive another ten or fifteen years bereft of the ability to do anything". ${ }^{15}$ While the doctors deliberate, Numada is longing for an animal to share his anguish and doubts, as he does not want to cause distress to his wife by confessing his despondency to her. "But if he told all to a bird (...) it would silently take it all in".16

One day his wife buys Numada a myna bird. "Its eyes were just like those of the hornbill". The author shares his hesitation about the dangerous operation with the bird. He has the impression his bird is laughing at him in response. "The laugh seemed at once to mock his cowardice and to offer encouragement". ${ }^{17}$ Like the hornbill, the myna bird is regarded by Numada as a companion. During his third operation his wife is so full of anxiety, she leaves the myna bird on the roof of the hospital and forgets all about it.

I wonder if it died in place of me?, wonders Numada afterwards. A feeling very close to certainty boiled up like hot water from his lacerated chest. (...) Numada's recovery after surgery, the source of such profound concern to his doctors, was nearly miraculous. (...) The myna bird died, as though in his stead. ${ }^{18}$

In later years, Numada joins the journey to India to visit a bird sanctuary, purchase a myna bird and release it to thank for his miraculous rescue.

Several questions arise when the stories are compared: Who is demanding the sacrifice? Who is giving the substitute animal? Who is sacrificing? Who suffers from the sacrifice? Who benefits from the sacrifice?

In the Genesis 22 story, the ram is recognized as a substitute for the son. Likewise, in Shūsaku Endō's "The Case of Numada," the bird is believed to be a substitute for Numada as well as a reference to Jesus, who, according to Endō, is believed to be a representative for humanity. ${ }^{19}$ Endō introduces the aspect of

\footnotetext{
15 Endō, Deep River, 79 .

16 Endō, Deep River, 80.

17 Endō, Deep River, 81.

18 Endō, Deep River, 82.

19 Endō, A life of Jesus, 178.
} 
substitution through animals, specially birds and dogs, referring to the significance of the eyes and the juxtaposition of the eyes of the bird and the dog with the compassionate eyes of the Jesus engraved on the fumie. ${ }^{20}$ In an attempt to bridge the communication gap between his non-Christian readers and the theme of his stories, Endō did not write about "the eye of Christ" until he wrote Silence. "Instead I tried to refer to it through different forms, such as the eye of a bird that dies". ${ }^{21} \mathrm{~A}$ fumie is a wooden or metal image of Jesus or Mary. It was used by the authorities during the persecutions of Christians in the Tokugawa Period (1600-1868). In this ritual, people had to trample on the image as a proof that they did not belong to the Christian religion or as a sign of abandonment of the Christian faith. In Shūsaku Endō's Silence, the main character, the priest Rodrigues, apostatizes by stepping on the fumie. When he raises his foot, the

Christ in bronze speaks to the priest: Trample! Trample! I more than anyone know of the pain in your foot. Trample! It was to be trampled on by men that I was born into this world. It was to share men's pain that I carried my cross. $^{22}$

According to Endō, Jesus becomes the substitute for the one who suffers. His redemptive suffering is a suffering of the substitute: He takes the pain of the ones who are suffering on his shoulders to the point of death. In Deep River, Endō compares the main character Ôtsu, who is a Jesus-like substitute, to the Suffering Servant in Isaiah 53 . Two chapter titles in Deep River concerning Ōtsu explicitly point to the bible passage; chapter eleven is called "Surely He Hath Borne Our Griefs" and chapter thirteen "He Hath No Form Nor Comeliness". In chapter two, Mitsuko, another central character, enters a chapel and reads a few sentences from the Isaiah 53 passage. ${ }^{23}$

Jacques Derrida, relating to Kierkegaard's epilogue of Fear and Trembling (written under the pseudonym of Johannes de Silentio) sees a connection of Genesis 22 and the Christian Passion story. To Derrida, there is an obvious analogy between the story of the sacrifice of a son by the father, and that of the son sacrificed by men and saved by a God who seemed to have abandoned him

20 Cf. Ascenso, Transcultural Theodicy in the Fiction of Shūsaku Endō, 248, and Mark Williams, Endō Shūsaku: A Literature of Reconciliation (London/New York: Routledge, 1999), 77.

21 Endō, "The Anguish of an Alien," 185.

22 Endō, Silence, 171.

23 Endō, Deep River, 44-45. 
or put him to the test. ${ }^{24}$ In this way, he states, Jesus' death has been seen as a substitute sacrifice, comparable to and associated with the near-sacrifice of Isaac. ${ }^{25}$ In the light of the compassionate eyes of the bird in Endō's narrative, which could stand for Jesus' compassion with the suffering main character, it is astonishing that Abraham ignores the eyes of Isaac when he raises the knife. An angel is needed to withhold Abraham.

A theme in both Genesis 22 and Endō's narrative concerns relinquishing one's life and surrendering one's future in an uncertain situation. Both Abraham and Numada are on the brink of risking death. On his way to respond to the voice that commanded him to sacrifice Isaac, Abraham is about to kill his only remaining son, thereby ending his own future as well. In Numada's case, his life is at stake as a consequence of his own wish for the lung operation despite the risks. In both stories, the substitute by the animal brings life.

Whereas Abraham remains silent, Numada expresses his doubts and anguish towards the bird. ${ }^{26}$ In response, the myna laughs at him, thereby acknowledging the paradoxical nature of the situation. At the same time, the bird's laughter breaks the tension and encourages Numada. In contrast, nothing seems to ease the loneliness of Abraham's dilemma.

\subsection{Two Differences}

Next I will elaborate on the two main differences between the Genesis 22 story and Endō's stories of animal substitutions: The (unknown) giver and the absent female. Furthermore, I will argue that these differences are related to each other. I start by reflecting on Levinas' critique of Kierkegaard's interpretation of Genesis 22 to enlighten the story's ethical element.

Levinas' ethic is based on the responsibility of the self for the other. The 'self' is not well-grounded, autonomous and in control; rather, it is naked, open. The responsibility for the other is expressed in terms referring to the condition of hostage and the call to substitute, which relieves the 'I' of the concern with his or her own being (and his or her own death). According to Levinas, the relation

\footnotetext{
24 Jacques Derrida, The Gift of Death \& Literature in Secret (Chicago/London: University of Chicago Press, 1999; 2008), 81.

25 Hereby suggesting that Isaac is an Old Testament 'type' of Jesus.

26 Abraham's silence has puzzled Kierkegaard. Kierkegaard recalls Abraham's strange answer to Isaac (that God will provide an animal) by stating that Abraham speaks but keeps his secret at the same time. Cf. Søren Kierkegaard, Fear and Trembling, Problem III, (tr. Walter Lowrie, New York: Doubleday, 1954, reprint 1941), 123-124. On the one hand, God has promised Abraham (who symbolizes Israel) a land, a people and a future in the form of a son. On the other hand, God is demanding the life of Abraham's son. This tension between the promise and its impossibility leads to a crisis that silences Abraham.
} 
between other and self (the ethical) is prior to the relation between God and self (the religious). From this perspective, Levinas criticizes Kierkegaard's interpretation of Abraham's absolute obedience to God, which distinguishes the God-human relationship from human relationships. Abraham seems to place unconditional obedience to God above the suffering of Isaac and Sarah, which renders Abraham's action, as interpreted by Kierkegaard, "violent" in the view of Levinas. ${ }^{27}$ According to Levinas, responsibility for the other human puts the 'I' in question. However, in Kierkegaard's Abraham, there is no trace of doubt. In his essay "On the Suspension of the Ethical," Martin Buber wonders why Kierkegaard takes for granted that it is God who summons Abraham to sacrifice Isaac, for it might have been Moloch, imitating the voice of God. The identity of the giver is important.

In the Deep River story, however, the substitute animal is given by an anonymous giver. It remains unclear whether the substitute bird, which stands for Jesus, who died for humanity, is given by God or by life itself. In Endō's stories on substitute animals, the relationship between the giver of the substitute animal and the 'I' is closely connected to the human relationships. The participation of Numada's wife is no denial of the divine. She may here serve as an instrument of the divine. The "love your neighbour" in Endō's stories seems to be equal to "love your God".

The substitute sacrifice in the story of Abraham and Isaac is thought to be given by an identified authority - God. As Nico Schreurs argues, one could read this form of reversed substitution as an equivalent of God giving up Egypt and the surrounding peoples to save the life of Israel (Isaiah 43:3-4). ${ }^{28}$ Biblical scholars of the School of Tübingen, who studied substitution and atonement, like Hartmut Gese, Bernd Janowski and others, stress the Hebrew Bible's term $k p r$, pointing to the relationship between God and sinful humanity, which does not keep the law. God is prepared to accept a ransom instead of human life. ${ }^{29}$ The kofer takes the place of the sinner, whose life, by his evil deeds, is forfeited.

\footnotetext{
27 Emmanuel Levinas, Proper names (Stanford: Stanford University Press, 1976), 76.

28 Nico F. M. Schreurs, "Substitution and Salvation: An Example of Systematic Theology in Dialogue with Exegesis," in Theology between Church, University and Society, Studies in Theology and Religion (STAR), vol. 6 (eds M. E. Brinkman et al.; Leiden: Brill, 2003).

29 H. Gese, "Die Sühne," in Zur biblischen Theologie: Alttestamentliche Vorträge (München: BEvTh, 1977), 85-106.
} 
Remarkable in texts such as Isaiah 43:3-4 and Exodus 21:28-32 is that God, the offended party, is the one who provides the ransom in the form of an animal in exchange for the life of the sinner. This seems to be a reversal of the sacrificial substitute required. ${ }^{30}$

In the story of Numada, the sacrifice is only a sacrifice because it is interpreted as such, in hindsight. The question who has given the bird remains unanswered. After an excursus on philosophical thoughts on giving and receiving, helping me to elucidate the concept of sacrificial substitution in the narratives, I will return to this theme of the anonymity of the giver.

\subsection{Between Giving and Receiving}

In both stories, the animals are received as a gift. Abraham recognizes the ram as the expected provision. Numada accepts the hornbill which is offered to him on his doorstep and he is touched by his wife's present of the myna bird.

In this section, I will interpret the sacrificial substitution in the narratives from the perspective of the gift. As the Dutch philosopher Van Velthoven has pointed out, a gift can only be a gift if there is someone who actively and consciously receives. ${ }^{31}$ The gift must be recognized as such. At first sight it may seem that the giver is the active one whereas the receiver remains passive. However, the receiver has a truly active part in the act of receiving. People can be willing to give, and act accordingly, but have to wait and see if their gift will be received. A gift implies the reception of the gift, and yet it is only the receiver who can accept it. This diminishes the difference between the giver and the receiver, for the acceptance is in itself a gift, intended and hoped for by the giver. By acting as though the gift will be accepted, the giver is expressing his/ her hope for future intersubjectivity. The act of giving and receiving assumes a bond between the one who gives and the one who receives. Katherine Rupp shows how in the Japanese context a gift can be experienced as an offense to a receiver. In Japan, gift-giving functions as a major means of social mobility. The giving of gifts is extremely important in patronage. Summer gifts and winter gifts are given to bosses, doctors, and teachers of one's children. On a macroeconomic level, politicians receive donations from industry and they, in their turn, intercede with bureaucracy on the latter's behalf. The gift-giving of humans to deities reflects the gift-giving among humans. The making of

$30 \quad$ Schreurs, "Substitution and Salvation," 129.

31 Theo van Veldhoven, Ontvangen als intersubjectieve act: Rede uitgesproken bij de aanvaarding van het ambt van bijzonder hoogleraar vanwege de Radboudstichting in de betrekkingen tussen christendom en wijsbegeerte aan de Universiteit van Amsterdam, September 29, 1980. 
offerings is thought to reinforce the cosmological hierarchy between humans and deities. ${ }^{32}$

The Japanese context emphasizes the economy of exchange that is part of giving and receiving. However, as Derrida has shown, the gift functioning in such a system of calculated exchange is no longer a gift in the strict meaning of the word. As soon as we give something to someone to receive something in return, we put that person in our debt, thus taking, not giving. The gift has become a measure to reach another aim, a form of calculation. By such a system the gift is destroyed as a gift. Derrida argues that the true gift is extravagant, exceeding what is strictly required, expecting no reciprocity. In this respect, gifts resemble sacrifices. Abraham had to sacrifice his youngest son, to give Isaac to God, without expecting anything in return. "The gift of death (...) has been accomplished without any hope of exchange, reward, circulation or communication". ${ }^{33}$

Furthermore, Derrida argues that for a gift to be a gift not only must the donor or recipient not perceive or receive the gift as such, that is, have no consciousness of it, but they must also forget it right away. ${ }^{34}$ A true gift forgets itself as a gift that has been given. All one could know of the gift would be the trace of its having already passed. The gift can only be known by way of a trace. The true gift cannot take place between subjects. Then who could meet the conditions of giving a gift? In Rethinking God as Gift, Robyn Horner suggests that Derrida's interpretation of the pure gift "precludes any possibility of belief that God is giver". ${ }^{35}$ One can conclude that only God or an anonymous giver is able to give a "pure gift", which is precisely the case in both stories.

\subsection{The (Unknown) Giver}

Jean-Luc Marion aims at transgressing the economic system of giving and receiving by reducing the gift to what he calls 'givenness'. ${ }^{36}$ Instead of the object, Marion stresses the process that precedes the act of giving. Marion's thoughts can be applied to the narratives in this chapter, because no object

32 Katherine Rupp, Gift-giving in Japan: Cash, connections, cosmologies (Stanford: Stanford University Press, 2003).

33 Derrida, The Gift of Death, 81.

34 Jacques Derrida, Given Time: 1. Counterfeit Money (Chicago/London: The University of Chicago Press, 1992), 16.

35 Robyn Horner, Rethinking God as Gift: Marion, Derrida, and the Limits of Phenomenology (New York: Fordham University Press, 2001), 197.

36 Jean-Luc Marion, Being Given: Towards a Phenomenology of Givenness (tr. Jeffrey L. Kosky; Stanford: Stanford University Press, 2002). 
is involved in the reversed sacrificial animal cases. In contrast to a given object, the life of the animals is given without a possibility of being repaid. Time, love, power and life are 'things' that can never be returned to the giver. Instead, Numada's freeing of the myna in India can be seen as accepting the gift of the animal by transmitting it. The anonymity of the giver prevents him from returning the gift, however, while at the same time it emphasizes the gift itself. The anonymity of the giver gives Numada, the 'givee', freedom to react. Numada finds himself "paying back" by writing children's books in which birds and dogs are main characters.

In his analysis of Abraham's sacrifice in terms of giving and receiving, Derrida values Abraham's gift as a "pure gift" that is, strictly speaking, "not of this world". ${ }^{37}$ According to Derrida, Abraham's gift avoids the manipulative do ut des principle. In this sense, Abraham's gift of his son is the sacrifice of the economy of sacrifice itself, because, according to Derrida, it is impossible Abraham could have benefited from this sacrifice, since his own future would be at stake in sharp contrast to God's promise to multiply Abraham's descendants. However, one could argue against Derrida that if Abraham had not been stopped, he would probably have murdered Isaac. In his critique of Kierkegaard, Levinas emphasizes not Abraham's response to the first voice, asking him to sacrifice Isaac, but his response to the second voice, asking him not to "lay his hand upon the lad". 38 The second voice brings Abraham back from the religious reign into the ethical reign. Levinas' interpretation gives reason to doubt whether the test is about Abraham's obedience to God. Abraham's loyalty to Isaac, Sarah and Eliezer might have been tested too. I will argue that for this last test Abraham seems to fail. To illustrate my point, I will turn to the second significant difference between Genesis 22 and "The Case of Numada" in Deep River: The role of the female in both narratives.

Abraham's wife Sarah is strikingly absent in Genesis 22. Abraham does not communicate with her, nor with his son Isaac or his friend Eliezer. Numada's wife, by contrast, plays an important part. She is the one who gives the bird to Numada as a present and neglects the bird in the hectic time around her

37 Jacques Derrida, from "On the Gift: A Discussion between Jacques Derrida and JeanLuc Marion," in God, The Gift and Postmodernism (eds J. D. Caputo and M. J. Scanlon; Bloomington: Indiana University Press, 1999), 59.

38 Genesis 22, 12 (King James Version). 
husband's surgery, which indirectly causes its substitute death. One could state that she unconsciously sacrifices the bird in Numada's stead, recognizing the sacrifice only after the bird's death. Various comments on the Genesis 22 story suggest that Isaac and Sarah suffered from the near-sacrifice. In Deep River, Numada and his wife benefit from the substitute death of the myna bird.

Derrida has observed the absence of "anything feminine whatsoever" in the Genesis 22 story. ${ }^{39}$ Sarah Coakley also points to this lacuna. ${ }^{40}$ The absence of Sarah in Genesis 22 might affirm that the necessary violence in such a cultic act of sacrifice is "condoning, justifying and even glorifying the abuse of the powerless (including, of course, children and women)". Coakley wonders if the "unthinking male obedience even unto death" is typical for the establishment of "patriarchal religion". ${ }^{41}$ She protests against the tendency to distinguish between sacrifice and gift in the postmodern discourse, ${ }^{42}$ for which she introduces an alternative. Searching for the lacking female participation in the story, Coakley turns to Isaac, inspired by Rembrandt's etching of Abraham's sacrifice (1655), which shows a nearly grown, rather feminine picture of Isaac. Referring to plural rabbinical midrash on the story, she suggests to see in Isaac an "honorable woman". As a grown-up, Isaac was not an unwilling victim, but cooperated in his sacrifice. Isaac, in the story depicted as a powerless boy, according to Coakley, is utterly transformed by the event. The divine interruption by the angel disrupts the negative father/son relationship, which was inclined toward violence. The angelic third lifts the spell of the patriarchal duality. The purification enhanced by the near-sacrifice ended a false sacrificial logic and a falsely idolatrous desire. In Coakley's view, the divine gift inevitably invites human sacrifice "if it is to draw us more deeply into participation in that gift". 43

This thought is consonant with the conception of evil in the literary work of Shūsaku Endō. According to Endō's main character in Deep River, Ōtsu, good and evil are not separate and mutually incompatible. "God makes

39 Derrida, The Gift of Death, 76.

$40 \quad$ See also e.g. Nancy Jay, Throughout Your Generations Forever: Sacrifice, Religion, and Paternity, (Chicago/London: The University of Chicago, 1992). Jay states that when Abraham was stopped and he offered a ram in place of Isaac, the latter received his life from the hand of his father. Jay sees the nearly sacrifice of Isaac as a spiritual 'birth' accomplished without female assistance.

41 Sarah Coakley, "In Defense of Sacrifice: Gender, Selfhood, and the Binding of Isaac," in Feminism, Sexuality, and the Return of Religion (eds L. M. Alcoff and J. D. Caputo; Bloomington: Indiana University Press, 2011), 17-38.

See e.g. Derrida, "On the Gift: A Discussion between Jacques Derrida and Jean-Luc Marion," 59 .

43 Coakley, "In Defense of Sacrifice: Gender, Selfhood, and the Binding of Isaac," 23. 
use not only of our good acts, but even of our sins in order to save us". This thought is familiar to the Buddhist conception of good-evil and its principle of "dependent origination" with good and evil being "completely dependent on one another". ${ }^{44} \mathrm{Sin}$, in Endō's view, is a state of infidelity in a relationship. ${ }^{45}$ Therefore, restoration of that relationship cannot occur without participation of the parties involved. Seen from the perspective of Endō's story, in which the woman participates by providing a substitute animal, I wonder if the lacking female element in Genesis 22 could account for the tragedy in Abraham's family relationships since the event. According to diverse rabbinical comments, the relationships of both Abraham and Sarah and Abraham and Isaac were frustrated by Abraham's willingness to sacrifice his son. Some comments have interpreted Sarah's sudden death in Genesis 23 as the result of maternal shock and grief over her husband's willingness to sacrifice their son. ${ }^{46}$ To demonstrate the significance and consequences of this difference in female participation, I will turn to several of Shūsaku Endō's stories on animal sacrificial substitution.

\subsection{Endō's Tales of a Substitute Death}

What is the function of the substitute sacrifice in Endō's stories? The death of the bird serves to reframe Numada's recovery in terms of a sacrifice. In a lecture at the University of Utrecht, Kathryn McClymond stated that "sacrifice is about storytelling". ${ }^{47}$ McClymond analyzed the execution of Saddam Hussein, on December 30, 2006, in terms of sacrifice. In the eyes of his followers, Saddam Hussein's death must have looked like a sacrifice for his people, as the date of the execution coincided with the Feast of the Sacrifice in Islam. This connection was partly due to Saddam Hussein's own efforts to present his death as a sacrifice in the media.

Likewise, the death - due to neglect - of the animal in "The Case of Numada" is rephrased as a sacrifice, a life-giving substitute death. Shūsaku Endō's

44 See e.g. Masao Abe, "The problem of evil," in Buddhist-Christian Dialogue: Mutual Renewal and Transformation (eds P. O. Ingram and F. J. Streng; Hawaii: University of Hawaii Press, 1986), 146.

45 Ascenso, Transcultural Theodicy in the Fiction of Shūsaku Endō, 234.

46 Stephen Stern interprets Sarah's death in Kiriath-Arba, a foreign land, as an indication that she left Abraham due to his role in the near-sacrifice of her son. Cf. Stephen Stern, "The Unbinding of Isaac," in Sacrifice, Scripture, and Substitution: Readings in Ancient Judaism and Christianity (eds A. W. Astell and S. Goodhart; Notre Dame: University of Notre Dame Press, 2011), 277.

47 Kathryn McClymond, Ritual gone wrong, a lecture held on September 22, 2010 at Utrecht University. 
short stories "A Forty-year-old Man" (1964) and "A Fifty-year-old Man" (1973) will enlighten this point. ${ }^{48}$ These short stories were sketches for the story of Numada in Deep River. Hence, the degree of repetition occurring in these short stories is considerable. Combining the various forms in which Endō attends to the theme of an animal substitute for a dying person creates an interesting picture that can contribute to the understanding of the stories written by Endō as well as to a deeper understanding of Genesis 22.

\section{2 "A Forty-Year-Old Man"}

In "A Forty-year-old Man," the main character is Suguro. A few days before his third operation, Suguro is visited by a priest who tells him that Jesus died for the sins of us all. Suguro's sins are clear. However, he does not confess them to the priest, but to his myna bird. Soon after, Suguro is visited by Yasuko, his wife's cousin with whom he had a secret sexual relationship. This happened several years previously, during the two weeks Suguro's wife Yoshiko was in the maternity ward of the hospital before delivering their baby. Yasuko became pregnant, and had an abortion. Although they never discussed the event, Suguro has the strong impression that his wife knows everything. The conversation at the hospital bed, during a visit of Yasuko and her husband to Suguro and his wife, conceals the past, although Yasuko's husband is the only one who is unaware of what has happened. "They all behaved as though nothing had happened," although "there were thorns and private meanings concealed beneath each of their remarks". 49 "Everyone is covering up for everyone else". 50

This conversation between family members mirrors the conversation between Abraham and his son. The painful issue is avoided. ${ }^{51}$ On the day of the surgery, Suguro asks to say goodbye to the bird.

You're the only one who knows what I could not tell the old priest in the confessional. You listened to me, without even knowing what any of it meant. ${ }^{52}$

48 Shūsaku Endō, "A Forty-year-old Man," in Stained Glass Elegies (Suffolk: Penguin Books, 1986), 11-27. In Japan, it is regarded as one of the most admired and most frequently anthologized of Endō's stories. And "A Fifty-year-old Man," in The Final Martyrs (New York: New Directions, 1994; 2009), 58-73.

49 Endō, "A Forty-year-old Man," 21.

$50 \quad$ Endō, "A Forty-year-old Man," 22.

51 Cf. Erich Auerbach, Mimesis: The Representation of Reality in Western Literature (tr. Willard R. Trask; Princeton University Press, 1953), 11.

$5^{2}$ Endō, "A Forty-year-old Man," 26. 
The operation succeeds. When Suguro asks about the bird, Yoshiko tells him how it died.

The nurses didn't have time to look after it. Neither did I. We fed it, but one really cold night we forgot to bring it back into the room. We shouldn't have left it out on the veranda all night. Suguro remains silent. "I'm sorry," continues Yoshiko, "but I feel as though it took your place (...) I buried it at home in the garden". 53

In this story, Yoshiko is the one drawing the conclusion that the bird died in place of her husband. She is also, as in "The Case of Numada," the one who leaves the bird on the roof or veranda. It is as if she unwittingly sacrifices the bird, so that her husband will live. Consequently, Endō's stories on substitute animal sacrifices seem not only to restore the relationship between the protagonist and God, but also between husband and wife. The bird's death functions as a catalyst in the family's relationships.

\section{3 "A Fifty-Year-Old Man"}

Nearly ten years after, Endō revisited this theme once again. In "A Fifty-year-old Man," however, the relationship between the giving and receiving parties is not so clear. In this short story, the animal is a dog named Whitey (instead of the former Blackie), the main character is Chiba, and the dying person is the protagonist's brother. The dog is an old mongrel, whose eyes remind Chiba of a dog which stared at him in Dalian many years ago, when he was forced to leave that dog behind. As his brother is in hospital in a critical situation, the condition of the dog deteriorates. The main character is troubled by dividing his attention between his brother and his dog. He cannot be with both of them at the same time. Chiba stays in the hospital, watching over his brother, who undergoes a successful operation. The next morning he returns home just in time to be beside his dying dog. The 'crime' in this story are the dancing classes that Chiba attends. The participants of the classes are in their twenties, whereas Chiba is over fifty. ${ }^{54}$ When he dances with a young partner, he imagines having sexual

\footnotetext{
53 Endō, "A Forty-year-old Man," 27.

54 This theme occurs once more in Shūsaku Endō's "A Sixty-year-old Man". The main character of this story is a writer, who is working on the draft of a book called Life of Jesus, a rewrite of $A$ Life of Jesus, which he wrote fifteen years earlier. He frequents a coffee shop on Sundays, where he secretly meets a high-school girl named Namiko. The author feels guilty and shameful about stealing glances at the young woman. Shūsaku Endō, "A Sixtyyear-old Man," in The Final Martyrs, 128-146.
} 
intercourse with her as he secretly inhales her sweat undiluted by perfume. The story suggests a vague relationship between the behavior of Chiba and the death of Whitey. Again, it is the wife of the protagonist who concludes: "He died in place of your brother". 55

\subsection{Substitute for Trespassing or a "Pure Gift"?}

In contrast to Abraham, the main characters in Endō's stories reflect on their past misbehaviour towards both God and their wives. Endō's three different stories indicate that the protagonists somehow deserve to be punished for their secret misconduct. ${ }^{56}$ When the Genesis 22 story is regarded in the light of these stories, the suggestion is that Abraham is 'paying' for previous misbehaviour. Some Jewish comments interpret the sacrifice of Isaac as a punishment for Abraham's earlier mistreatment of Ishmael, his elder son, whom he expelled from his household at the request of his wife Sarah. According to this

55 Endō, "A Fifty-year old Man," 73. The self-reflection in the three stories on substitute animal sacrifice by Endō is typical for the literary genre of his writing. Shishōsetsu is a Japanese literary genre in which transparency, sincerity, subjectivity, and autobiographical character result in a kind of confession. Shishōsetsu is based on the assumption that realism in the novel can only be founded on authenticated personal experience. Fiction and autobiography thus overlap when the author concentrates on narrating his or her own life and feelings. For detailed information on shishōsetsu, see e.g. The Rhetoric of Confession: Shishōsetsu in Early Twentieth-Century Japanese Fiction (ed. E. Fowler; Berkeley: University of California Press, 1988). According to Mark Williams, Shūsaku Endō belongs to the third generation of shishōsetsu writers, who attempted to expose the conflicts within the Self. This Self is in constant confrontation with an 'other' - within or without itself - urging the protagonist(s) to seek reconciliation. Cf. Williams, Endō Shüsaku: A Literature of Reconciliation.

$5^{6}$ This relationship can also be found in a combination of the story of "The Case of Numada" and "Life," another story with autobiographical elements by Shūsaku Endō in The Final Martyrs, 114-127. In the district Hokkaidō where the young Endō/Numada lives, Chinese, who had lived there for a long time, were regarded second rate. His mother hires $\mathrm{Li}$, one of the Chinese children, as a houseboy. One day Numada picks up a stray dog. His parents are not pleased with the filthy Manchurian dog and order Numada to get rid of it. Li, however, washes Blackie and secretly hides the dog in the coal shed near the house. After a couple of days Numada's parents agree to the dog's staying. A month later Li is fired. The padlock to the coal shed had been opened and half of the supply of coal had disappeared. Although he denies it, Li is accused of the theft. He is been fired and sent away. In "Life," however, the reader learns about another reason for Li being fired. In this autobiographical story, the main character is an eleven-year-old boy, who is so bored by his depressed mother, who is grieving about the bad relationship with the boy's father, that he steals her ring and sells it. Li, the houseboy, is accused instead and sent away. 
view, Abraham failed to show compassion for this oldest son, so God punished him by ostensibly failing to show compassion for Abraham's youngest son.

In line with the two differences between Genesis 22 and Endō's narratives, the reactions of the protagonists show a third difference: Their reaction to the animal's substitute death. One of the untold elements in the Genesis 22 story is Abraham's reaction to the gift. While Numada expresses his gratitude for receiving a substitute, it remains unclear whether Abraham thanks God explicitly. One could argue that the reverse occurs: God thanks Abraham for his obedient attitude of absolute loyalty (Gen. 22:15-19).

In contrast to Abraham, Numada makes great efforts to give form to his gratitude. The reason for Numada to subscribe to the tour to India lies in his desire to visit a bird sanctuary, where he can set a bird free, as a sign of recognition of the myna bird which had died in his place. "Do you remember those nights?" he asked the captured myna he eventually buys, just before he lets it go. Numada tells this new bird about those nights when he confessed his anxiety and loneliness to a similar bird. A bird that died "as though in his stead". Then he opens the cage and frees the bird.

Watching its laughable movements from behind, Numada felt as though the heavy burden he had carried on his back for many years had been removed.

After releasing the bird, he realizes that animals are 'reborn' in his children's stories.

From this perspective, the substitution can be regarded as a subtle form of reincarnation. ${ }^{.7}$ Analogue to Endō's description of Jesus who continued to live in the hearts of his disciples, the birds are restored to live in Numada's children's books. From the stories preceding "The Case of Numada" as well as "The Case of Numada" itself, it becomes clear that the relationship between the man and woman benefits from the sacrifice of the substitute animal. In the airplane to India, Numada buys perfume to thank his wife. "A Forty-yearold Man" ends with Yoshiko saying that "everything will be all right now". And despite her distaste for Whitney, in "A Fifty-year-old Man," the wife of Chiba "plucked several cosmos flowers" to lay on the dead dog's head. In contrast, as

57 Ascenso points to other characters in Deep River, in whom the Buddhist concept of reincarnation might be recognized: the dying wife of Isobe and her 'rebirth' in her husband; the volunteer Gaston as the Jesus figure who is 'reborn' in Kiguchi's dying friend and, finally, the dying Ōtsu and his 'resurrection' within Mitsuko. Cf. Ascenso, Transcultural Theodicy in the Fiction of Shūsaku Endō, 269. 
Heleen Zorgdrager states, Sarah, who is excluded from information and participation, is - symbolically speaking - the one who is sacrificed, namely as the mother of her child. ${ }^{58}$ In my view, the difference between the supposed lack of gratitude of Abraham and the abundant gratitude of Numada is in line with the differences in their relationship to their nearest and dearest.

8

\section{Conclusion}

From comparing and confronting the stories of 'reversed' sacrifice in Genesis 22 and "The Case of Numada" (and its previous sketches), the following characteristics have emerged. God or a divine power provides the sacrificial animal (hence: Reversed, for God or a divine power also receives the sacrifice). The animal sacrifice serves as a substitute. By the substitute death of the animals the incomprehensibility of God/the paradoxical situation is broken and the protagonists' lives are saved. In the case of Numada, the substitute animal has an additional function as a silent witness to Numada's confession. In the Japanese stories, the sacrifice is performed without witnesses or priests, without a ritual and without the protagonists knowing. The substitution is recognized as a gift only in hindsight. The animal dies in loneliness, at the moment that the protagonist should have died. Characteristic of the animal substitutes is their clumsiness; they are laughable figures. However, their vulnerability, relativism and availability seem to encourage the main characters to surrender themselves to the unknown.

Compared to Numada, Abraham seems to be a violent figure. In his obedience to God he is willing to suspend the ethical. He is not even moved by the other right beside him, who is his own son. Therefore he ceases to communicate. Abraham uses Isaac as a means to receive an absolute relation to the absolute, the price of which seems to be radical solitude and consequent disturbance of his family relationships. Unlike Sarah in Genesis 22, the wives in Endō's stories are playing an active and decisive role, which gives the reader hope for an interpersonal reconciliation. In the Japanese story, the substitute is experienced as a dōhansha, a motherly constant companion who remains

$5^{8}$ Heleen Zorgdrager, "The sacrifice of Abraham as a (temporary) resolution of a descent conflict? A gender-motivated reading of Gen. 22," in The Sacrifice of Isaac: The Aqedah (Genesis 22) and its Interpretations (eds E. Noort and E. Tigchelaar, Leiden/Boston/Köln: Brill, 2002), 182-197 (196). 
loyal up to the end. ${ }^{59}$ The substitute animal sacrifice enables a new future for the protagonists and hence provokes gratitude.

59 See e.g. Ascenso, Transcultural Theodicy in the Fiction of Shūsaku Endō and Williams, Endō Shüsaku: A Literature of Reconciliation for a discussion of the concept of dōhansha in Endō's literary work. 